\title{
Importance of National Policy and Local Interpretation in Designing Payment for Forest Environmental Services Scheme for the Ta Leng River Basin in Northeast Vietnam
}

\author{
Dam Viet Bac ${ }^{1}$, Delia C. Catacutan ${ }^{1} \&$ Hoang Minh $\mathrm{Ha}^{2}$ \\ ${ }^{1}$ World Agroforestry Center (ICRAF), Hanoi, Vietnam \\ ${ }^{2}$ Embassy of Vietnam, Washington, D. C., USA \\ Correspondence: Dam Viet Bac, World Agroforestry Center (ICRAF), No. 1, Lot 14A, TrungHoa Street, Yen \\ Hoa Ward, CauGiay District, Hanoi, Vietnam. Tel: 84-437-834-645 Ext. 12. E-mail: d.vietbac@cgiar.org
}

\author{
Received: December 1, 2013 Accepted: January 15, 2014 Online Published: January 19, 2014 \\ doi:10.5539/enrr.v4n1p39 URL: http://dx.doi.org/10.5539/enrr.v4n1p39
}

\begin{abstract}
The Leng River basin in BacKan province, northwest Vietnam hosts critical natural resources where lessons learnt from the pilot project of payment for forest environmental services (PFES) in Lam Dong and Son La provinces can be applied. PFES is broadly defined as an economic instrument that facilitates payments of forest environmental service flows to forest dwellers. The passage of a national PFES Decree in Vietnam where the K-factor framework was used to determine the payment level of environmental services created both opportunities and challenges in the design and implementation of PFES schemes. This paper presents how the national PFES policy was adapted, and how lessons in the pilot provinces were considered in developing a local PFES scheme. Important considerations and criteria for determining K-factors to standardize payments for similar environmental services, as well as the proposed PFES scheme for the Leng River Basin are discussed. The paper concludes that national policy framework and local interpretation of K-factors are crucially important in designing a PFES scheme that meets the realistic and pro-poor elements of PES. Finally, a PFES scheme must have detailed implementing guidelines that are developed with local stakeholders.
\end{abstract}

Keywords: environmental services, PES mechanism, negotiation, benefit sharing, K factors, Vietnam

\section{Introduction}

Payment for environmental services (PES) is a voluntary transaction where a well-defined environmental service (e.g. buffering water flows, carbon sequestration, etc.) is bought by a buyer (people who benefit from its provision) only if the provider (local landholders or residents) ensures the delivery of a specific service (Wunder et al., 2008). In 2008, the Government of Vietnam passed Decision 380, which piloted the implementation of Payment for Forest Environmental Services (PFES) in Son La and Lam Dong provinces for a two-year period (2008-2010). The K-factor framework was used to determine the value to be paid to forest owners based on forest status, types and origin of the forest, and degree of difficulty of forest management. By the end of the pilot implementation in 2010, the Government promulgated Decree 99, which adopted PFES as a national policy, mandating nation-wide implementation (Vietnam Government, 2010). Within the context of the PFES policy framework, a number of PFES initiatives have been initiated by international non-government organizations (INGOs) in different parts of Vietnam. However, applying the K-factor in the design of PFES schemes in different areas, has been challenging - complexity and impracticalities were usual complains about the K-factor. It appeared that site-specific variations in forest conditions could not be unanimously addressed by the K-factor. Several studies have highlighted issues surrounding the application of K-factor and recommendations were made to reduce its complexity (Note 1). This paper discusses the proposed application of K-factor and a PFES scheme for the Ta Leng or Leng River Basin, Bac Kan province, in the northeast region of Vietnam. The study was undertaken by the World Agroforestry Centre (ICRAF) in Vietnam through the 'Rewards for Use of and Shared Investment for Pro-poor Environmental Services' (RUPES) project in collaboration with the Pro-Poor Partnerships for Agroforestry Development (3PAD) project, which are both funded by the International Fund for Agricultural Development (IFAD). The Ta Leng River Basin was selected for this study due to its significance as a RAMSAR site. Data was collected between 2010 and 2011 using both qualitative and quantitative data 
gathering techniques.

\section{Review of PES Concepts}

\subsection{The PES Concept}

Payment for Environmental Services (PES) is an instrument where those that benefit from environmental service flows reward or pay the environmental stewards. Swallow et al. (2007) defines PES as a range of mechanisms linking ecosystem stewards and environmental services beneficiaries and intermediaries in a market for ecosystem services. Identified ecosystem services included in most market schemes are (i) carbon sequestration; (ii) provision of habitat for endangered species; (iii) protection of landscapes; and (iv) various hydrological functions related to the quality, quantity, or timing of freshwater flows from upstream areas to downstream users. Payments or incentives can be in form of cash or in-kind rewards, such as access to land or markets, capacity building, and recognition of identity and rights (Van Noordwijk et al., 2004).

As an economic instrument, developers of PES schemes should identify a reward level or a contract price reflective of the value of conservation while also compensating landowners for the cost of their foregone opportunity to exploit the resource, otherwise, if the sum is too low, many potential suppliers may not participate because the income from changing the land use could be more than the sum they were offered. But if payment is too high, the conservation budget could be exhausted quickly and the project could fail to deliver an adequate level of environmental service. A more reliable method is required to estimate payments that incorporate both the hidden variables and heterogeneity across the farmers and/or groups of farmers (Hoang \& Do, 2011). In line with this thinking, Van Noordwijk and Leimona (2010) introduced four principles for the development of PES schemes: (i) Realistic: payment should be linked to measurable change in levels of environmental services; (ii) Conditional: payment should be based on performance and, if possible, outcomes; (iii) Voluntary: payment should based on free, prior, informed consent of all parties; and (iv) Pro-poor: payment should not increase inequity.

Institutions are important for a successful PES system, as they play a fundamental role in supporting all aspects of operation of PES markets, particularly in countries with relatively weak governance structures (Alana et al., 2009). Five context-specific factors influence a successful take-off of PES in Asia: (i) diverse governance structures and regulatory frameworks; (ii) risk of high transaction costs from high population density and low land holdings per capita; (iii) weak property rights for forest and agricultural land; (iv) insufficient hydrological data and understanding of watershed services; and (v) low awareness of PES (Alana et al., 2009; Huang \& Upadhyaya, 2007).

\subsection{Payments for Forest Environmental Services (PFES) in Vietnam}

Through Decision 380/2008/QD-TTg, the Government of Vietnam started a pilot program for PFES in 2008, which was followed by nationwide implementation of PFES at the beginning of 2011, pursuant to Government Decree 99, which laid the legal foundation for provinces to demand hydropower, water and tourism companies to pay a certain percentage of their income to relevant environmental services providers. The types of forest eligible for PFES are protection, special-use, and production forests. Table 1 shows the forest environmental services, ES users, and the payment levels, which are to be determined using the K- factor formula, as shown below. The basic financial flow for PFES in Vietnam according to Decree 99 is shown in Figure 1. The payment level (payment to households contracted for forest protection) is calculated based on the K-formula:

The amount of payment to an Norm of payment environmental service $(\mathrm{ES})=$ for one ha of forest $x$ provider in a year (VND) (VND/ha)
Area of forest managed and used by an ES provider (ha)
$\mathrm{K}$ factor

Where:

Norm of payment for 01 hectare of forest (VND/ha): is determined by the total amount of payment for forest environmental services (after subtracting the reasonable management costs);

Forest area used and managed by ES providers of the forest environmental services: is the area allocated, leased, contracted for a long term the forest use right at the time of declaration for payment;

Factor K: Shall be determined based on the following factors: (i) Forest status (ability to provide forest environment services); (ii) Type of forest (special-use, protection or production); (iii) Origin of forest (natural forest, planted forest); Unfavorable and favorable conditions for forest protection (social and geographical factors). 
The K-factor formula differentiates the amount of payments made to forest owners, which is to be decided by the Provincial People's Committees (PPCs) in accordance with local conditions. Four types of K factors have been applied: (i) K1- Status of forest; (ii) K2- Forest types/purposes; (iii) K3- Origin of forest; and (iv) K4- Degree of difficulty in forest protection, including social and geographic factors. Simplistically, K-factor refers to the criteria to be used in determining the payment level, with values assigned to each. As mentioned earlier, the provinces of Son La and Lam Dong were selected for piloting PFES from 2008 to 2010 under the guidance of Decision 380 .

Table 1. Types of forest environmental services covered by the PFES Programme and level of payments

\begin{tabular}{|c|c|c|}
\hline Service Users & Forest Environmental Services & Level of Payment \\
\hline Hydropower companies & $\begin{array}{l}\text { Protection and prevention of soil erosion and sedimentation } \\
\text { in reservoirs, rivers and stream beds; regulating and } \\
\text { maintaining water sources }\end{array}$ & $\begin{array}{l}20 \mathrm{VND} / \mathrm{kWh}(0.1 \$ \mathrm{US} \\
\text { cent } / \mathrm{kWh})\end{array}$ \\
\hline $\begin{array}{l}\text { Organizations and } \\
\text { individuals engaged in } \\
\text { tourism business }\end{array}$ & $\begin{array}{l}\text { Protection of natural landscape and conservation of } \\
\text { biodiversity }\end{array}$ & $1-2 \%$ of profits \\
\hline $\begin{array}{l}\text { Clean water production } \\
\text { and supply companies }\end{array}$ & $\begin{array}{l}\text { Regulation and maintenance of water sources for clean } \\
\text { water production }\end{array}$ & $\begin{array}{l}40 \mathrm{VND} / \mathrm{m}^{3} \quad(0.2 \$ \mathrm{US} \\
\left.\text { cent } / \mathrm{m}^{3}\right)\end{array}$ \\
\hline $\begin{array}{l}\text { Industrial production } \\
\text { companies }\end{array}$ & Regulation and maintenance of water sources for production & No detailed regulation \\
\hline No detailed information & $\begin{array}{l}\text { Absorbing and storing } \mathrm{CO}_{2} \text {; conserving aquaculture } \\
\text { environments, natural seeds, feeds and genetic biodiversity }\end{array}$ & No detailed regulation \\
\hline
\end{tabular}

Source: Decree No. 99/2010/ND-CP on PFES, Vietnam Government (2010). 

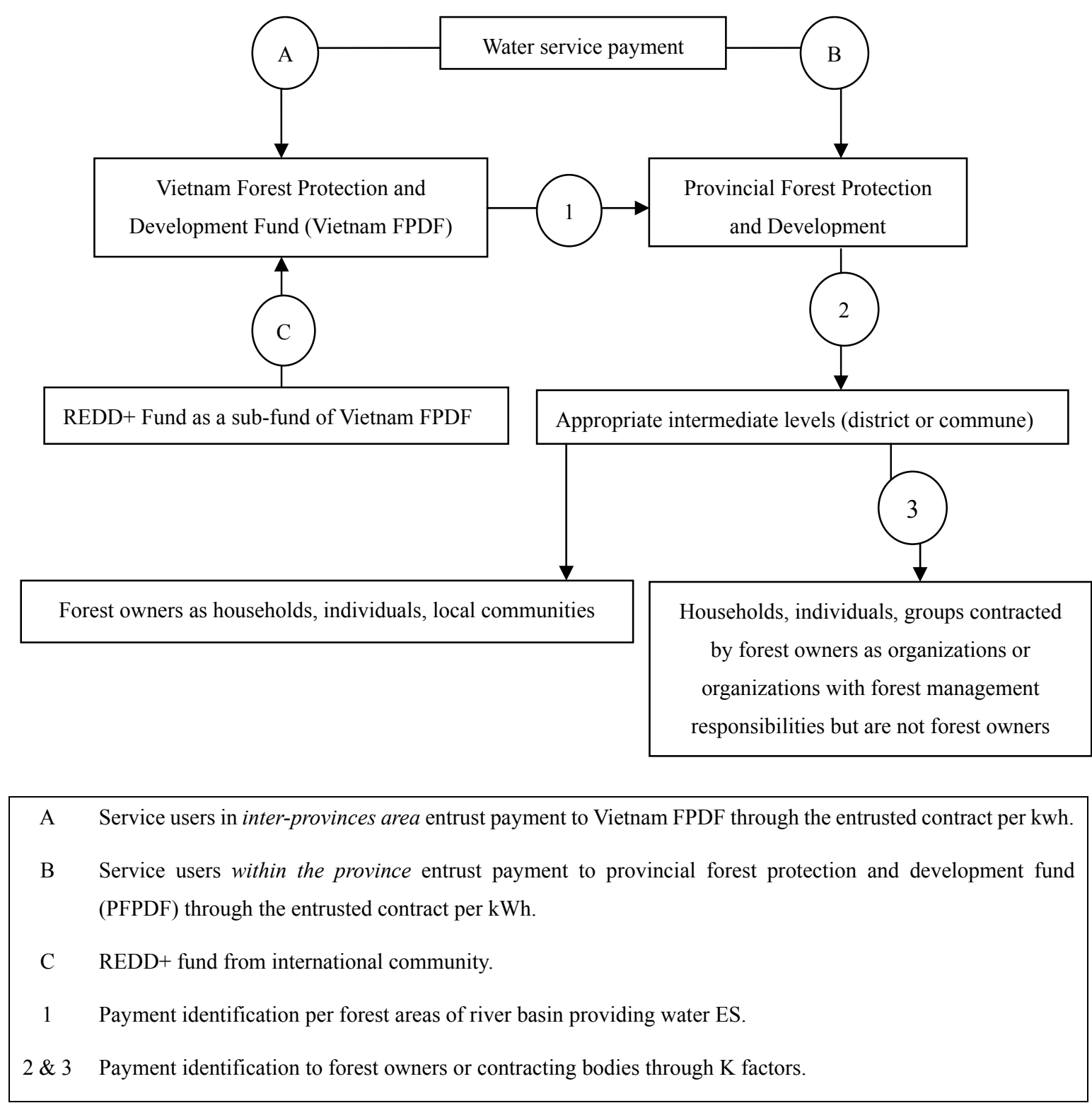

Figure 1. The basic financial flow for PFES in Vietnam according to Decree 99 (Source: Decree 99/2010/ND-CP)

The national PFES policy (Decree 99) was formulated based on lessons learnt from the two-year pilot PFES Program in 2008-2010. The Ministry of Agriculture and Rural Development (MARD) was tasked to formulate the Decree to provide further implementation guidance. The user fee for every $1 \mathrm{KWh}$ of electricity generated by hydropower companies is VND 20 (US\$0.1) and VND 40/per $\mathrm{m}^{3}$ (US\$0.2 cent) for commercial drinking water. This amount was decided upon by the Legislation Department of MARD based on existing literature during the formulation of Government Decision No. 380/QD-TTg (Vietnam Government, 2010).

Furthermore, Vietnam is amongst few pilot countries of the United Nations' Reducing Emissions from Deforestation and forest Degradation (UN-REDD) programme. Since the national PFES policy preceded the UN-REDD programme, it was suggested that the institutional structure for a REDD+ Fund in Vietnam should be based on the existing structure of Vietnam's Forest Protection and Development Fund (Figure 1), which was created in part to manage PFES revenues (UN-REDD Vietnam, 2010). Specifically, it was suggested that REDD+ revenues will be managed through a sub-fund of the FPDF. Epule et al. $(2013,2014)$ mentioned that as a mechanism of PFES that enables tree planters to absorb the shocks experienced due to incomes lost due to deforestation and small scale forestry, REDD reinforces the enabling conditions for successful reforestation. 


\subsection{Challenges and Lessons Learnt in the Pilot Implementation of PFES in Son La and Lam Dong Provinces}

\subsubsection{K-Factors}

In Son La, the K-factor was applied based on the origin of the forest (e.g., natural, plantation) and type of forest (protection, production, special use), whereas magnitude of forest impact in addition to the four K-factors was employed in Lam Dong province. But because there was no clear or updated data on status of forest development, and despite efforts to measure indirect forest values to unpack the K-factors into several sub K-factors, variations of forest status could still not be determined, making it more difficult to apply the K-factors as defined in Decision 380. Moreover, as a new concept, the K-factor was very difficult to interpret and implement even by PFES implementers; in the end, the K-factor was assumed to be ' 1 ' $(\mathrm{K} 1 * \mathrm{~K} 2 * \mathrm{~K} 3 * \mathrm{~K} 4=1)$ and payments were made uniformly to ES sellers in both provinces. Households in Son La and Lam Dong received, on average, US\$5.6/ha in 2009 and between US\$9.0/ha and US\$12.7 in 2010, despite differences in forest type, origin, status and difficulty in forest management. Furthermore, the contracted households were not entitled to choose which forest to protect. Those who protected the more accessible part of the forest were of advantaged compared to households who conducted protection activities deep in the forest (Hoang \& Do, 2011). In other words, there was no spatial consideration of the payment. Monitoring activities were also limited or not sustained, as the monitoring scheme was complex, costly and inefficient. Since the very beginning of the pilot PFES, implementers in both pilot provinces have had challenges--they fervently complained about applying the $\mathrm{K}$-factor formula and offered several suggestions to ease its implementation. But due to lack of examples by which they can refer to, they ended up over-simplifying the PFES scheme, relegating the essence of the K-factor framework. As this study suggests, modifying the K-factor framework based on local stakeholders' conditions and preferences provide ease in designing a local PFES scheme.

\subsubsection{Conditionality}

Conditionality means that payments are made only if the service provider complies with the contract. To receive payment for their services, environmental service providers must commit to forest protection, attested to by both forest owners and the commune authority. The contract should also specify that both forest managers or owners and service provider household (individual or a group) must comply with regulations on the monitoring mechanisms. Enforcing conditionality in PES schemes requires supportive policy and legal framework, effective monitoring and sanctioning non-compliance. However, due to difficulties encountered in differentiating payment levels using the K-factor formula, the pilot PFES in Son La and Lam Dong applied a uniform payment to ES sellers, assuming that all forests are the same. This move was reinforced by sheer difficulties of PFES implementers to enforce 'conditionality' without an effective monitoring system, which would entail additional costs to the PFES pilot scheme if they were to set up one. Low or absence of conditionality is often a characteristic of government-led PES prototypes, which have the advantage of lower start-up costs and administrative cost efficiency. As the study in the Ta Leng River Basin suggests, conditionality of PFES scheme can be enhanced by getting local stakeholders' buy-in of the PFES concept.

\subsubsection{Addressing Poverty}

Markets for ecosystem services are not primarily intended to reduce poverty, but rather to generate new funding for and reduce the costs of achieving conservation goals. The Vietnamese pilot PFES policy however, emphasized poverty reduction as an objective. In fact, it is envisioned to increase household incomes from forest protection (Luan, 2011); hence, the contracted households were to be selected based on poverty criteria and preference was given to ethnic minorities. However, in Son La, poverty reduction could not be achieved since the poorest households were either landless or were managing smaller forest areas. It was recognized that a pro-poor PFES scheme can be clearly linked with poverty reduction targets and goals, and involve landless individuals. Payments must be sufficient to interest poor ES providers, and a margin over and above the provision costs may have to be paid. Conversely, fixed rates could put large rents in the pockets of poor, low-cost service providers and improve their welfare substantially. But low-cost providers are not always poor, so fixed payments for PES is also not recommended as a poverty alleviation strategy, where efficiency losses can be significant. Our study in Ta Leng River Basin suggests that engaging local stakeholders or ES providers in determining and designing a PFES scheme is a necessary step in addressing the poverty goal of PFES.

\subsubsection{Lack of Understanding of Roles by ES Sellers}

Since the government has been implementing massive reforestation projects, local people could not differentiate their role in the PFES scheme from that of being contractees of reforestation activities or recipients of cash or input subsidies for tree planting and forest protection activities. Forest-dependent people could not see themselves as ES sellers and could thus not appreciate their role, which lend themselves to being passive 
participants of the scheme. Appreciation of their roles as ES sellers is highly important so that they develop a deeper commitment and can actively participate in the PFES scheme. Furthermore, Epule et al. (2013) discussed the importance of population involvement in both the design and implementation of reforestation projects as a major contributor to success in tree planting. Here we suggest that monetary payments for ES should be accompanied with sensitization and capacity building activities, so that providers assimilate and become committed to their roles.

\section{Methodology}

\subsection{Site Description}

Ta Leng River Basin is wholly contained within the Nang River basin, in Bac Kan province, in the northeast region of Vietnam (Figure 2). Bac Kan province is about 170 kilometers north of Hanoi, the country's capital and 200 kilometers south of the border with China. The topography of the area is complex, with many valleys, hills and rocky mountains. The total population of Bac Kan province in 2009 was 296,500 with main ethnic communities being Tay, Kinh, and Dao. Poverty in Bac Kan province is amongst the highest in Vietnam (MoLISA, 2011). Agriculture and forestry are the main sources of livelihoods. Bac Kan's forests are classified into three main types, namely protection, production and special use wherein, an estimated $65.64 \%$ is production forest, $28.53 \%$ protection forest and 5\% under 'special use (DoNRE, 2011).

The province is host to highly significant ecosystem, the Ba Be National Park, which is a Ramsar site and an ASEAN Heritage Park. Covering an area of 10,048 hectares, Ba Be National Park supports the only significant natural mountain lake in the country and is the most important wetland in Vietnam. Ba Be Lake provides water for irrigation during the dry season and helps mitigate flood from four rivers during the wet season. Threats to the site include infrastructure development, bird hunting, water pollution, and forest clearance for agriculture production (The Ramsar Convention, 2012).

$\mathrm{Na}$ Hang and Ta Leng River Basins are two watersheds of Ba Be that were identified by scientists at the World Agroforestry Centre (ICRAF-Vietnam) as potential sites for developing a PES scheme to enhance watershed functions. Rapid Hydrological Appraisal (RHA) was conducted to define the buyers and sellers of watershed services in the basin. RHA is an integrated tool that is used to assess the hydrological functions of a watershed in relation to land use, which helps to bridge the often constrained communication gap between three types of knowledge on watershed functions namely, local ecological knowledge, public and policy-shapers ecological knowledge; and modeler/scientist ecological knowledge. Specifically, the Ta Leng River watershed lies in the valley of the Phiabjooc mountain of $\mathrm{Ba}$ Be District with a total area of 16,708 hectares. The topography is sloping with many small tributaries to the river. The population is around 15,000 , of which, $80 \%$ are ethnic people.

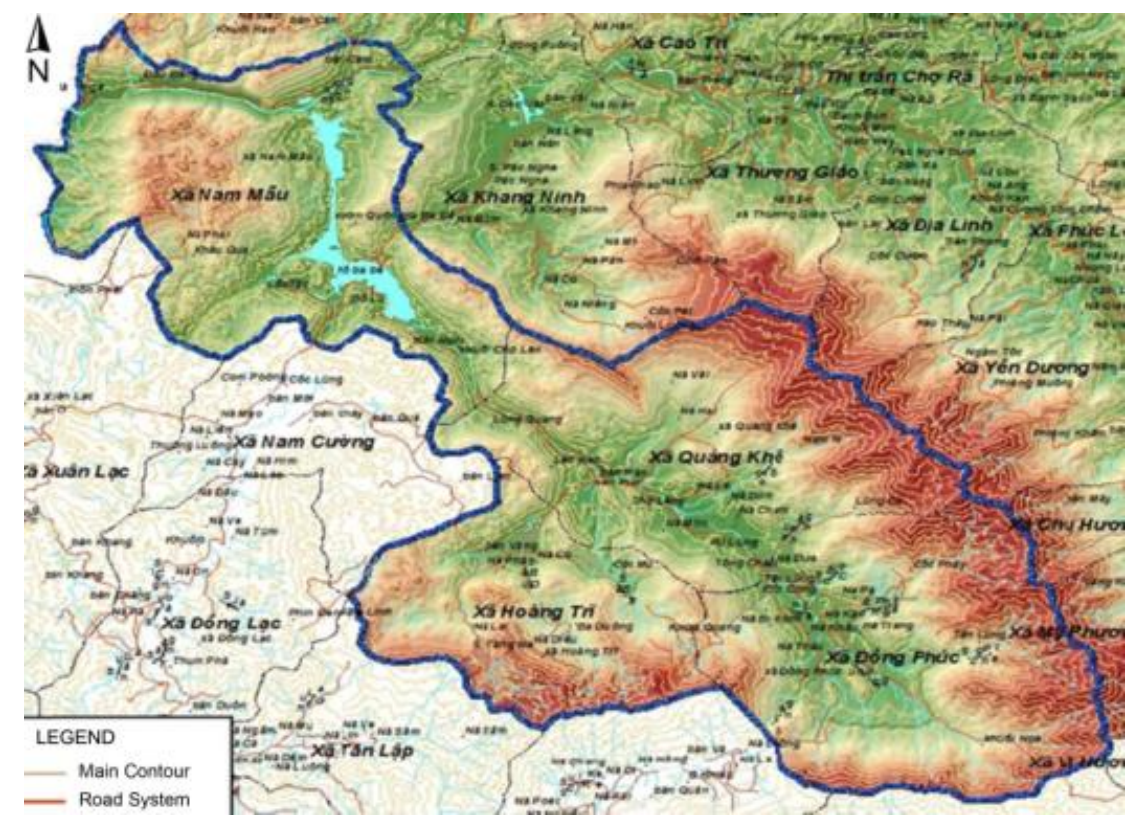

Figure 2. Ta Leng River Basin 


\subsection{Data Collection and Analyses}

The study involved three key steps, namely understanding the national PFES context in Vietnam, participatory RHA, and PFES design as the final step (Table 2). Several policy documents were reviewed to understand the national context of PFES (Table 3). To comprehensively and effectively assess the suitability of, and to develop a prototype PFES mechanism for the Ta Leng River Basin that can be potentially adopted in other provinces or nationally, RHA which includes several tools, was used to generate and interpret diverse knowledge systems such as local, scientific and public-policy makers knowledge over land use patterns and their relations to watershed functions. Such tools include, GIS-based land cover analyses and Participatory Landscape Analysis (PaLA), which was designed through packaging appropriate Rapid Rural Appraisal/Participatory Rural Appraisal (RRA/PRA) tools/methods in combination with agro-ecological analysis to capture local knowledge relevant at different temporal and spatial scales. PaLA can be used in scoping studies and for awareness raising among community members on problems and issues connected with ecological and administrative boundaries. In addition, Participatory Analysis of Poverty, Livelihoods and Environment Dynamics (PAPOLD) was also conducted to capture specific issues and there linkages. PAPOLD is not only participatory, but also dynamic and comparable. It is a refinement of the Stages of Progress (SoP) developed by Anirudh Krishna of Duke University in the USA that was modified by ICRAF Vietnam and applied to find out: (i) local perceptions related to environmental issues; (ii) environmental 'hot spots' in the watershed area; (iii) poverty conditions and related social economic environmental issues; and (iv) factors that contribute to environmental service changes, (v) Potential mechanisms for PES. To elicit public-policy makers knowledge and preferences, a series of stakeholders' consultation workshops were organized in Bac Kan province and in Hanoi City during the PFES development process (from October 2010 to October 2011), which contributed not only in ensuring the suitability of the PFES scheme to local conditions, but also to building local capacity for successful implementation. The last step of RHA, which is the hydrological modeling was however, not applied in the study due to limited hydrological data in the Basin.

Table 2. Research steps and methods

\begin{tabular}{|c|c|}
\hline Research steps & Methods \\
\hline \multicolumn{2}{|c|}{ Step 1. Literature review to understand the national PES perspective. } \\
\hline \multirow[t]{4}{*}{$\begin{array}{l}\text { Understanding local and national perspectives on } \\
\text { PFES }\end{array}$} & $\begin{array}{l}\text { Literature review of the pilot PFES implementation } \\
\text { (Catacutan, 2012) }\end{array}$ \\
\hline & Scoping study for K-factor identification \\
\hline & $\begin{array}{l}\text { Surveys in Son La, Lam Dong and Thua Thien Hue } \\
\text { provinces }\end{array}$ \\
\hline & $\begin{array}{l}\text { Policy dialogues with national and provincial leaders } \\
\text { in Bac Kan }\end{array}$ \\
\hline \multicolumn{2}{|l|}{ Step 2. Rapid Hydrological Appraisal (RHA)in Bac Kanprovince. } \\
\hline Understanding land use patterns in the basin & Land cover analysis \\
\hline $\begin{array}{l}\text { Analysis of upstream and downstream } \\
\text { interactions }\end{array}$ & Participatory landscape analysis (PaLA) \\
\hline \multirow[t]{2}{*}{$\begin{array}{l}\text { Identifying livelihood options to estimate the } \\
\text { opportunity costs for PFES at community level. }\end{array}$} & $\begin{array}{l}\text { Participatory Analysis of Poverty, Livelihoods and } \\
\text { Environment Dynamics (PAPOLD) }\end{array}$ \\
\hline & In-depth case studies \\
\hline
\end{tabular}

Step 3. Designing the Ta Leng River PFES scheme.

Using data obtained from steps 1 and 2, this stepincludes elicitation, brainstorming and building consensus on the design of PFES scheme, and involves three sub-steps
Focus group discussions with village, commune, district and provincial stakeholders

Key informant interviews with national and provincial stakeholders 
Table 3. Policy documents reviewed in the study

\begin{tabular}{|c|c|}
\hline Year & Documents \\
\hline 2003 & Law No. 13/2003/QH11 dated on 26/11/2003 of National Assembly on Land Law 2003 \\
\hline 2004 & Decree No. 181/2004/ND-CP dated on 29/10/2004 of the Government on implementation of the Land Law \\
\hline 2004 & Law No. 29/2004/QH11 dated on 3/12/2004 of National Assembly on Forest Protection and Development Law \\
\hline 2006 & $\begin{array}{l}\text { Decree No. } 23 / 2006 / \mathrm{ND}-\mathrm{CP} \text { dated } 3 / 3 / 2006 \text { of the Government on the implementation of the law on forest protection } \\
\text { and development }\end{array}$ \\
\hline 2006 & $\begin{array}{l}\text { Decision No. 174/2006/QD-TTg dated on 28/7/2006 of Prime Minister approving the overall scheme on protection and } \\
\text { sustainable development of ecological environment and landscape of The Cau River basin (six provinces, including Bac } \\
\text { Kan province) }\end{array}$ \\
\hline 2008 & Decree No. $120 / 2008 /$ ND-CP dated on 1/12/2008 of the Government on river basin management \\
\hline 2008 & Decree No. $05 / 2008 /$ ND-CP dated on 14/01/2008 of the Government on Forest Protection and Development Fund \\
\hline 2008 & $\begin{array}{l}\text { Decision No. 111/2008/QĐ-BNN dated on 18/11/2008 of Ministry of Agriculture and Rural Development on regulations } \\
\text { on organization and operation of Forest Protection and Development Fund at provincial level }\end{array}$ \\
\hline 2008 & $\begin{array}{l}\text { Decision No. 114/2008/QĐ-BNN dated on 28/11/2008 of Ministry of Agriculture and Rural Development on setting up } \\
\text { Vietnam Forest Protection and Development Fund. }\end{array}$ \\
\hline 2008 & $\begin{array}{l}\text { Decision No. 128/2008/QĐ-BNN dated on 31/12/2008 of Ministry of Agriculture and Rural Development on regulations } \\
\text { on organization and operation of Vietnam Forest Protection and Development Fund }\end{array}$ \\
\hline 2008 & $\begin{array}{l}\text { Decision No. 380/QĐ-TTg dated on 10/04/2008 of the Government on forest environmental services payment (period of } \\
\text { 2008-2009) }\end{array}$ \\
\hline 2008 & $\begin{array}{l}\text { Resolution No. } 30 \mathrm{a} / 2008 / \mathrm{NQ}-\mathrm{CP} \text { dated on } 27 / 12 / 2008 \text { of the Government on the support program for fast and } \\
\text { sustainable poverty reduction in } 61 \text { poor districts. }\end{array}$ \\
\hline 2009 & $\begin{array}{l}\text { Circular No. 34/2009/TT-BNNPTNT dated 10/6/2009 of Ministry of Agriculture and Rural Development on criteria for } \\
\text { forest identification and classification }\end{array}$ \\
\hline 2009 & $\begin{array}{l}\text { Decree No. } 99 / 2009 / \mathrm{ND}-\mathrm{CP} \text { dated } 02 / 11 / 2009 \text { of the Government on sanctioning administrative violations in forest } \\
\text { management, forest protection and forest product management }\end{array}$ \\
\hline 2010 & $\begin{array}{l}\text { Decree No. } 99 / 2010 / \mathrm{NĐ}-\mathrm{CP} \text { dated on } 24 / 09 / 2010 \text { of the Government on policy for forest environmental services } \\
\text { payment }\end{array}$ \\
\hline 2010 & $\begin{array}{l}\text { Decision No. 2284/QĐ-TTg dated on 13/12/ } 2010 \text { of the Government on approving proposal on implementing Decree } \\
\text { 99/2010/NĐ-CP of the Government dated on 24/9/2010 on forest environmental services payment }\end{array}$ \\
\hline 2012 & $\begin{array}{l}\text { Circular No. 85/2012/TT-BTC dated on 25/5/2012of Ministry of Finance on guiding financial management for Forest } \\
\text { Protection and Development Fund }\end{array}$ \\
\hline 2011 & $\begin{array}{l}\text { Decision No. } 135 / \mathrm{Q} Đ-B N N-T C L N \text { dated on } 25 / 01 / 2011 \text { of Ministry of Agriculture and Rural Development on } \\
\text { approving implementation plan for proposal on implementing Decree 99/2010/NĐ-CP on PFES }\end{array}$ \\
\hline 2011 & $\begin{array}{l}\text { Circular No. 80/2011/TT-BNNPTNT dated on 23/11/ } 2011 \text { of Ministry of Agriculture and Rural Development on guiding } \\
\text { methods to determine payment for forest environmental services }\end{array}$ \\
\hline 2012 & $\begin{array}{l}\text { Circular No. 60/2012/TT-BNNPTNT dated on 9/11/2012 of Ministry of Agriculture and Rural Development on } \\
\text { regulating principles and methods to determine forest area in the watershed for forest environmental services payment. }\end{array}$ \\
\hline 2012 & $\begin{array}{l}\text { Inter-Circular No. 62/2012/TTLT-BNNPTN-BTC dated on 16/11/2012 of Ministry of Agriculture and Rural } \\
\text { Development and Ministry of Finance on guiding management and utilization of funds collected from forest } \\
\text { environmental services payment. }\end{array}$ \\
\hline 2012 & $\begin{array}{l}\text { Circular No. 20/2012/TT-BNNPTNT dated on 7/05/2012 of Ministry of Agriculture and Rural Development on guiding } \\
\text { order and procedures for acceptance check and making payment for forest environmental services }\end{array}$ \\
\hline 2012 & $\begin{array}{l}\text { Decision No. 119/QĐ-TCLN-KHTC dated on 21/03/ } 2012 \text { of VNFOREST on provisional regulation on procedures for } \\
\text { establishing contracts on payment for forest environmental services }\end{array}$ \\
\hline
\end{tabular}




\section{Results and Discussions}

\subsection{PFES Stakeholders}

The provincial, district and commune governments were mobilized to implement the pilot PFES in Son La and Lam Dong provinces. Water supply and hydropower companies, as well as nine tour agencies in both provinces were identified as ES beneficiaries. Households, meanwhile, were the main forest owners, ES providers and ES payment recipients. The government in this case, acted as 'intermediary' between ES sellers and buyers.

\subsection{Upstream and Downstream Interaction in the Ta Leng River Basin}

Land cover analyses showed that the forest cover is denser in the lower portion of the basin, contrary to local peoples' notion that poor forest cover upstream of the Ta Leng River Basin affects downstream water quantity. Comparative analyses of issues identified by stakeholders in three villages in Dong Phuc, Quang Khe and Nam Mau communes are shown in (Table 4). Of the 17 sub-catchments found in Quang Khe and Dong Phuc communes within the Ta Leng River Basin, two were subjected to further investigation, in relation to the above claim. Through spatial and temporal analyses, it was found that within each sub-catchment, water availability in downstream villages depends not only on the forest cover in upstream villages, but also on the area under terraced rice cultivation. The size of rice fields in upper villages can be linked to low water quantity downstream - the larger the terraced rice fields in upstream villages, the less water was found downstream. Soil erosion was also pervasive everywhere, from upstream to villages downstream of the Ta Leng River Basin. Strong waterflows have caused riverbank erosion that destabilized the riparian area. Stakeholders also raised concerns on drought during the dry season and flooding in the rainy season. Forest protection and conservation were considered long-term solutions for maintaining water supply both by upstream and downstream villagers, while building irrigation channels for efficient distribution and utilization of irrigation water was suggested as a quick-fix solution to the problem of water scarcity in downstream villages. 
Table 4. Main issues identified by stakeholders in three villages in upper, middle and downstream sections of Leng River basin

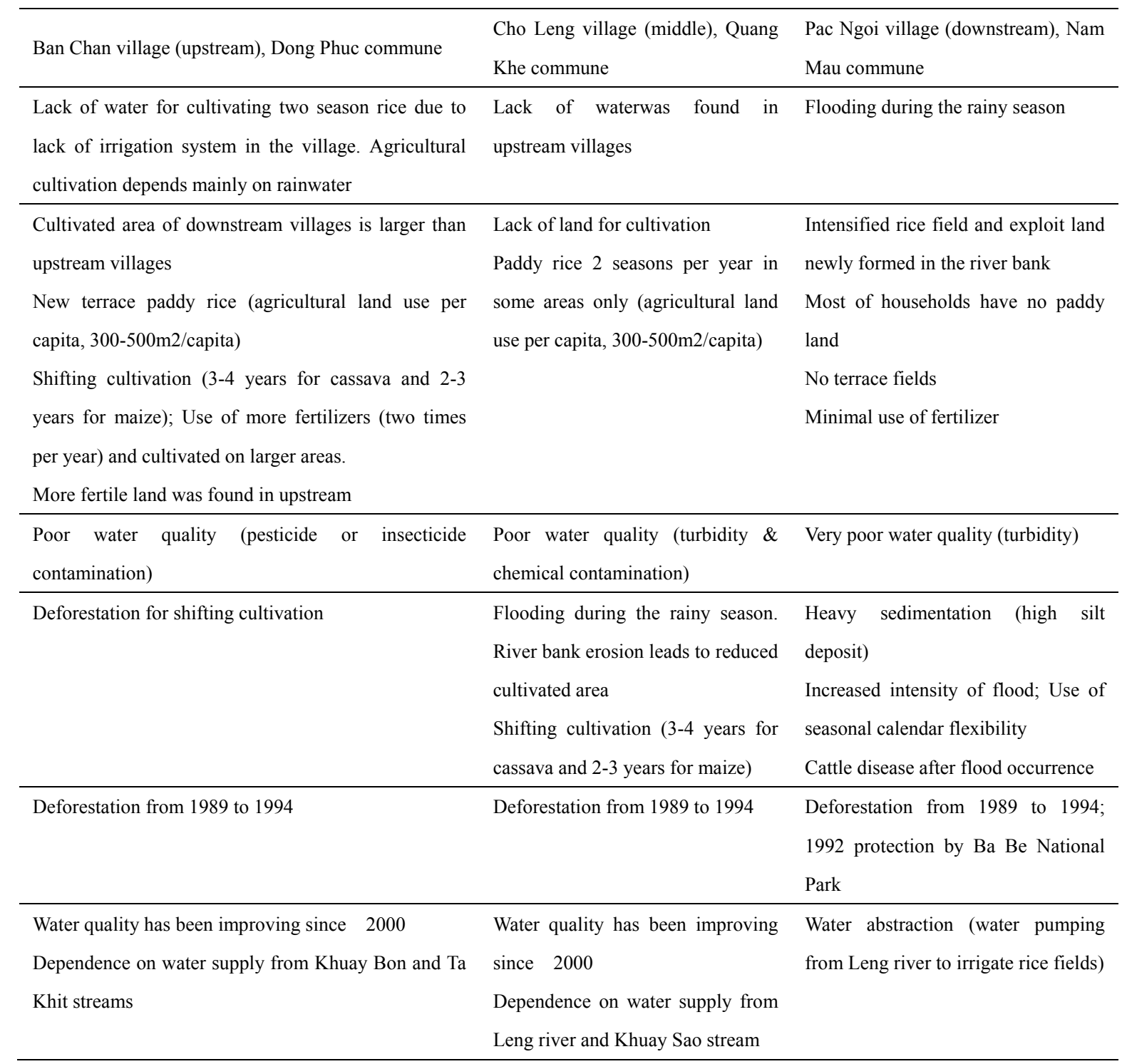

\subsection{Developing the PFES Scheme}

From the RHA conducted in 2008, three potential environmental services were recommended for consideration by a PFES scheme, namely water services, carbon sequestration and landscape beauty. The first two services have more relevance for $\mathrm{Ba} \mathrm{Be}$ National Park while landscape beauty was considered important to Ba Be District. The environmental services sellers/providers and buyers/beneficiaries in $\mathrm{Ba} \mathrm{Be}$ district were also identified, namely the Bac Kan PFPDF, Ba Be National Park, Commune Peoples' Committee (CPC) and households.

\subsubsection{Estimating Payments for Water Services Based on Decree 99}

Four steps were carried out to estimate the income that a Ba Be District PFES scheme could provide to forest owners such as: (i) watershed delineation; (ii) forest delineation; (iii) estimation of payment of water use based on the hydropower plant's output; and (iv) calculating annual payment per unit area of the forest (Table 5). In the third step, the water use payment was calculated by multiplying the total energy output (in $\mathrm{kWh}$ ) of the hydropower company with $20 \mathrm{VND}$, as per Decree 99, This amount was then, paid to Vietnam's FPDF by the water and hydropower companies in Na Hang. The money paid referred to as 'ES fund'. This amount represents the annual ES payment for protecting a hectare of a forest, which in this case, is equal to 200,000 VND/ha (Note 2) of forest/year with a K factor of "1" (for all types of forests) or $8.8 \mathrm{USD} / \mathrm{ha}$. As the K-factor had not been decided by the provincial government, there was no difference in the amount of payments to forest owners 
according to forest status, type and origin of the forest, and level of difficulty in forest management.

Table 5. Procedures for estimating payments for water services according to Decree 99 in Ta Leng River Basin

\begin{tabular}{|c|c|c|}
\hline Steps & & Output \\
\hline 1 & $\begin{array}{l}\text { Mapping the borders of Nang and Leng River } \\
\text { watershed }\end{array}$ & Topography map of Nang River watershed \\
\hline 2 & $\begin{array}{l}\text { Defining the total forest area of Nang and Leng } \\
\text { River watershed }\end{array}$ & $\begin{array}{l}\text { Total forest area of Nang River watershed is } 96,602 \text { ha. } \\
\text { In which total forest area of Leng River watershed is } \\
16,708 \text { ha. }\end{array}$ \\
\hline 3 & $\begin{array}{l}\text { Estimating the amount to be paid by } \mathrm{Na} \text { Hang } \\
\text { hydropower plant from using water service }\end{array}$ & $\begin{array}{l}\text { Energy output of } \mathrm{Na} \text { Hang hydropower plant: } 1,238 \\
\text { million } \mathrm{kWh} \text { in } 2009,1,019 \text { million } \mathrm{kWh} \text { in } 2010 \text {. }\end{array}$ \\
\hline 4 & $\begin{array}{l}\text { Estimation of amount of environmental services } \\
\text { payments per hectare of forest in Nang River and } \\
\text { Leng watersheds }\end{array}$ & $\begin{array}{l}\text { One hectare of forest in Nang and Leng River basin is } \\
\text { paid by Na Hang hydropower plant at USD } 8.8 / \text { ha/year in } \\
2010 \text { ( } 10 \% \text { of transaction cost of indirect payment has } \\
\text { already been deducted) }\end{array}$ \\
\hline
\end{tabular}

The exchange rate used was approximately US\$1 $=20,000 \mathrm{VND}$.

\subsubsection{Financial Flow of PFES in the Ta Leng River Basin}

The local stakeholders in Bac Kan province identified the K-factors to be used in determining the payment level of ES provision based on the guidelines set by Decree 99. As indicated above, five layers of stakeholders in the Ta Leng River Basin can be further grouped into two: intermediaries and sellers. Group one consists of Vietnam FPDF, Bac Kan PFPDF, Ba Be National Park and Commune FPDF while group two consists of households and individuals (Table 6). In terms of financial flow of PFES, reference was made to Decree 99 where ES funds were supposedly paid to Bac Kan PFPDF by Vietnam's FPDF who will then, channel the funds to Ba Be National Park and the Commune People's Committee who in turn, distributes payments to individual households (Table 6). As shown, of the total amount transferred by Vietnam FPDF to Bac Kan PFPDF, a maximum $10 \%$ is budgeted for the PFPDF's activities and 5\% is reserved for contingencies. The remaining $85 \%$ is transferred /paid to Ba Be National Park and Commune People's Committee where 10\% (of the $85 \%$ ) is retained as management fee, while $90 \%$ is for paying ES providers for undertaking forest protection activities. 
Table 6. Financial flow and benefit distribution of PFES in the Leng River basin based on Decree 99

\begin{tabular}{|c|c|c|c|c|}
\hline Stakeholders/actor & $\begin{array}{l}\text { Financial } \\
\text { flows }(\%)\end{array}$ & $\begin{array}{l}\text { Management } \\
\text { fee }(\%)\end{array}$ & $\begin{array}{l}\text { Contingency } \\
\text { fee }(\%)\end{array}$ & Basis of payment \\
\hline Vietnam Forest Protection and & 100 & 0.5 & 0 & Forest area of the river basin \\
\hline Development Fund & & & & \\
\hline $\begin{array}{l}\text { BacKan PFPDF } \\
\qquad \downarrow\end{array}$ & 99.5 & 10 & 5 & 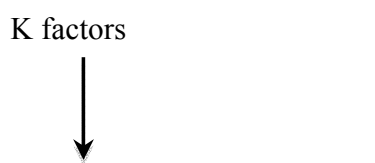 \\
\hline Ba Be National Park and & $>=85$ & 10 & 0 & Proposed for Leng River \\
\hline Commune FPDF & & & & Basin \\
\hline 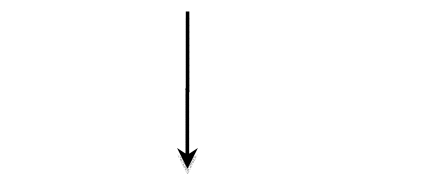 & & & & $\begin{array}{l}\text { Negotiated and mutually } \\
\text { agreed } \mathrm{K} \text { factors based on } \\
\text { local conditions }\end{array}$ \\
\hline $\begin{array}{l}\text { Village ES providers as forest } \\
\text { owners\& households/individuals } \\
\text { contracted by forest owners }\end{array}$ & 90 & 0 & 0 & $\downarrow$ \\
\hline
\end{tabular}

\subsection{Negotiating K- Factors and Payment Schemes}

\subsubsection{K- Factors at the Level of Bac Kan PFPDF and National Park and Commune}

During the consultation and planning process that was facilitated by ICRAF researchers and 3-PAD staff, local stakeholders suggest that $\mathrm{K}$ - factors be applied evenly in all districts in Bac Kan province during a pilot period of 2-3 years. Based on the experience in Son La province during the pilot phase of PFES, two options relating to $\mathrm{K}$-factors were discussed and considered by Bac Kan stakeholders. The first option focuses on the capacity of forests to provide environmental services, and involves three K-factors such as forest status (K1), forest type (K2), and forest origin (K3). The second option emphasizes efficiency of payments and local awareness on PFES through forest protection and development activities, and employs only two of the three K-factors, namely forest types (K2) and forest origin (K3).

The first option is favorable because it suggests that the payment is contingent upon delivery of quality environmental services, or conditional (e.g., if local people have produced quality forest, they would get higher payments). The challenge however lies in determining the baseline status of forests, since sufficient and reliable data from the National Forest Inventory and Planning Institute (FIPI) could not be obtained. As a consequence, the second option was preferred by local stakeholders due to lack of baseline data on forest status. On a positive note, this option is straightforward, simple and suitable to the management capacity of local stakeholders, and can be adjusted overtime.

4.4.2 Proposed Payment Scheme at the Level of the National Park, Commune and Individual or Household ES Sellers

Negotiation is important in designing a PFES scheme. If properly carried out, it enables stakeholders to reach an agreement in various aspects of a PFES scheme such as contract design, payment level, rights, liabilities and criteria for monitoring. At this level, applicable K-factors and other considerations were discussed by stakeholders who agreed to apply two K-factors (K2- forest type and K-3 forest origin) and three additional criteria to determine the payment level: (i) level of investment required for protecting different types of forests; (ii) contribution of PFES to poverty reduction and improving the livelihoods of local people; and (iii) local people's expected income from forests.

Having agreed on the above criteria and the $\mathrm{K}$ factors to use, a pilot PFES scheme for the Ta Leng River Basin was developed with two levels of payment. The first level of payment will be between Bac Kan PFPDF and Ba Be National Park and Commune based on two K- factors, namely K2- forest type and K3- forest origin. 
Necessary technical information was to be obtained from the annual forest inventory data of the Bac Kan Provincial Department of Forest Protection. This approach is expected to incur lower transaction costs. The second level of payment will be between Ba Be National Park and Commune to individual households or groups of households contracted by forest owners. At this level, more negotiations and consultation among local actors were needed before an agreement was reached on the criteria to be used in selecting the K-factors to be applied in the PFES scheme. The negotiations sought to clarify the different expectations of all actors, agree on realistic targets, define conditional rewards, define appropriate monitoring procedures, and promote fairness. Both cash and non-cash payments were considered. The latter may involve payments through infrastructure provision such as meeting halls and road networks so that landless members of the community who could not participate in a PFES scheme can also benefit. In addition, complementary programs such as extension services, capacity building, and post-payment activities were to be facilitated. As learned from the experience of the pilot provinces, understanding the roles of local communities in the PFES scheme is highly important, which can be achieved through sensitization and capacity-building activities. It was also recognized that cash payments alone could not sufficiently address households' economic needs, so post-payment extension activities associated with the PFES scheme should run in parallel with monitoring activities.

4.4.3 Stakeholder Preferences on Benefits From or Payment for Environmental Services in the Ta Leng River Basin

The above choice of payments by ES sellers corroborates with the results of a related study that was also supported by ICRAF in 2012, in another village of the Ta Leng River Basin. Eastman (2012) (Note 3) reported that stakeholders' gave highest preference for cash incentives followed by inputs for public infrastructure, then by land use rights certificates (LURCs) for forestland. Local people indicated that cash payments should be higher than US\$10/ha or the cost norm of Programme 661 (Note 4) (1998-2010). Stakeholders added that they prefer ES payments in form of purpose-oriented cash for inputs for infrastructure projects and agricultural production rather than receive them directly from the government. Furthermore, they prefer to manage infrastructure projects themselves and volunteer labor, or allow individual households to buy specific agricultural inputs as needed.

\section{Conclusion}

The national PFES policy provided guidance in developing a PFES scheme for the Ta Leng River Basin. The Basin hosts an array of forest resources, which are important for tourism and hydropower generation, and to the integrity of $\mathrm{Ba} \mathrm{Be}$ National Park--a world Ramsar site. PFES is expected to help forest communities earn additional income from protecting and maintaining the quality of forest resources. Learning from the experience of the PFES pilot provinces, a desirable PFES scheme for the Leng River Basin is one where (i) a uniform $\mathrm{K}$-factor for the provision of similar environmental services is applied; (ii) local perspectives and other important considerations are taken account in deciding which K-factors to apply at the local level; and (iii) both monetary and in-kind payments/benefits are considered. The main innovation in the Leng River PFES scheme from the pilot PFES provinces are the (i) employment of 2-levels of payments; (ii) consideration of relevant criteria in deciding the K-factors to be applied; and (iii) negotiations between Ba Be National Park and Commune FPDF and village households as ES providers. The main argument running through this experience is that, a national PFES policy is necessary to launch national conservation efforts and provide overall direction, but a local PFES scheme can be developed through inclusive negotiations, wherein local stakeholders deliberate and collaborate with everyone involved. Clearly, both the national PFES framework and local interpretation of local stakeholders are crucial in designing PFES schemes that meets the 'realistic' and 'pro-poor' elements of PFES. Engaging stakeholders in a meaningful way is a step towards meeting the pro-poor ambition of PFES. While this study is limited to a single river basin, valuable insights can be drawn by other provinces in Vietnam who are, by virtue of Decree 99, considering a PFES scheme as a means to protect forest resources and enhance environmental services without jeopardizing local livelihoods. The main issue encountered in the study is the lack of hydrological and rainfall data in the site, limiting the hydrological assessment in relation to land use change. Future research in the Ta Leng River Basin would require climatic and water data, as well as monitoring and evaluation of the PFES scheme. Nevertheless, this experience is already a source of learning for other countries wishing to develop a national PFES programme.

\section{Acknowledgements}

The study reported in this paper was conducted under the projects: (i) Rewards for, Use of and Shared Investment in Pro-poor Environmental Services (RUPES) and (ii) Pro-poor Partnership for Agroforestry Development in Bac Kan Province (3PAD). The authors acknowledge the financial support of IFAD and the 
collaboration with the 3PAD project.

\section{References}

Alana, G. (2009). Potential and limitations of Payments for Environmental Services (PES) as a means to manage watershed services in mainland Southeast Asia. International Journal of Common, 3(1), 16-40. Retrieved from http://www.thecommonsjournal.org

Bac Kan Department of Natural Resources and Management (DoNRE, 2011). (2010). Bac Kan Land Use Planning for the first period 2011-2015 (p. 149). Report.

Catacutan, D. C. (2012). Major challenges and lessons learnt from payments for forest environmental services in Vietnam.

Retrieved from http://rupes.worldagroforestry.org/sites/default/files/publications/PES\%20policy\%20brief\%20ENG_1.pdf

Eastman, D., \& Catacutan, D. C. (2012). Implications for REDD+ Benefit Distribution System in Vietnam. ASB Policy Brief No. 27. ASB Partnership for the Tropical Forest Margins, Nairobi, Kenya.

Epule, T., Changhui, P., \& Laurent, L. (2013). Enabling Conditions for Successful Greening of Public Spaces: The Case of Touroua, Cameroon Based on Perceptions. http://dx.doi.org/10.1007/s11842-013-9246-2

Epule, T., Changhui, P., Laurent, L., \& Zhi, C. (2013). Policy options towards deforestation reduction in Cameroon: An analysis based on a systematic approach. http://dx.doi.org/10.1016/j.landusepol.2013.09.004

Hoang, M. H., \& Do, T. H. (2011). Assessing the potential for, and designing, a 'Payment for Environmental Services'scheme in BacKan province, Vietnam. Technical Report.ICRAF, Vietnam.

Huang, M., \& Upadhyaya, S. K. (2007). Watershed-based payment for environmental services in Asia. Winrock International Working Paper No. 06-07. OIRED. Retrieved from http://www.oired.vt.edu/sanremcrsp/documents/PES.Sourcebook.Oct.2007/Sept.2007.PESAsia.pdf.

Luan, T. D. (2011). Payment for forest environmental services schemes. Case study in Da Nhim and Lac Duong communes in Lam Dong Province (p. 20). ICRAF, Vietnam.

Ministry of Labour - Invalids and Social Affairs (MoLISA). (2011). Survey result of assessment of poor and nearby poverty groups, year 2011. Decision No. 375/QD-LDTBXH (p. 6). MoLISA.

Swallow, B., Kallesoe, M., Iftikhar, U., van Noordwijk, M., Bracer, C., Scherr, S., ... Rumley, R., (2007). Compensation and Rewards for Environmental Services in the Developing World: Framing Pan-Tropical Analysis and Comparison. ICRAF Working Paper No. 32. Nairobi: World Agroforestry Centre. Retrieved from http://www.worldagroforestry.org/downloads/publications/pdfs/wp14963.pdf

The Ramsar Convention on Wetland. (2012). The Annotated Ramsar List of Wetlands of International Importance. $\quad$ Retrieved November 17, 2012, from http://www.ramsar.org/cda/en/ramsar-documents-list-annotated-ramsar-15775/main/ramsar/1-31-218\%5E15 775 4000_0

UN-REDD Vietnam. (2010). Design of a REDD-compliant benefit distribution system fro Vietnam. Retrieved from http://www.un-redd.org/Newsletter6_Viet_Nam_BDS/tabid/3280/language/en-US/Default.aspx

van Noordwijk, M., Chandler, F. J., \& Tomich, T. P. (2004). An introduction to the conceptual basis of RUPES: rewarding upland poor for the environmental services they provide (p. 46). ICRAF-Southeast Asia, Bogor.

van Noordwijk, M., \& Leimona, B. (2010). Principles for fairness and efficiency in enhancing environmental services in Asia: payments, compensation, or co-investment? Ecology and Society in press. Retrieved from http://www.worldagroforestry.org/sea/Publications/files/poster/PO0250-10.PDF

Vietnam Government. (2010). Decree No. 99/2010/ND-CP on the Policy for Payments for Forest Environmental Services. Retrieved from http://www.vietnamforestry.org.vn/view_news.aspx?nid=298

Wunder, S., Engel, S., \& Pagiola, S. (2008). Taking stock: a comparative analysis of payments for environmental services programs in developed and developing countries. Ecological Economics, 65, 834-852. http://dx.doi.org/10.1016/j.ecolecon.2008.03.010

\section{Notes}

Note 1. Major challenges and lessons learnt from Payments for Forest Environmental Services (PFES) schemes in Vietnam. 
Note 2. Amount of payment per one hectare of forest/year was deducted $10 \%$ management fee and $5 \%$ contingency by BacKan PFDPF, National Park and Commune.

Note 3. Implications for a REDD+ Benefit Distribution System in Viet Nam. ASB Policy Brief No. 28, ASB Partnership for the Tropical Forest Margins, Nairobi, Kenya.

Note 4. The programme, Decision 661/QD/TTg (1998) of the Prime Minister on rehabilitating the five million hectares of new forest, together with the protection of existing forests in order to increase forest cover to $43 \%$ of the Vietnamese territory by 2010 .

\section{Copyrights}

Copyright for this article is retained by the author(s), with first publication rights granted to the journal.

This is an open-access article distributed under the terms and conditions of the Creative Commons Attribution license (http://creativecommons.org/licenses/by/3.0/). 